- This review demonstrates a lack of consistency in the direction of effect of oral health outcome measures with different frequencies of routine dental check.

- Six-monthly routine dental checks or any other specific frequency of routine dental check for adults or children cannot be advocated on the basis of existing evidence.

- There is a need for further primary research to investigate the relative effectiveness of routine dental checks of different frequency in terms of the separate impact on caries, periodontal disease, oral cancer and patient-centred oral health outcomes.

\title{
The effectiveness of routine dental checks: a systematic review of the evidence base
}

\author{
C. F. Davenport, ${ }_{1}^{1}$ K. M. Elley, ${ }^{2}$ A. Fry-Smith, ${ }_{1}^{3}$ C. L. Taylor-Weetman ${ }^{4}$ and R. S. Taylor ${ }^{5}$
}

\begin{abstract}
Aims To systematically review the effectiveness of routine dental checks of different recall frequencies in adults and children.

Methods Search methods included electronic bibliographic databases up to March 2001, relevant internet sites, citation checking and contact with experts and professional dental bodies. Inclusion criteria: (1) Study design: any; (2) Population: deciduous, mixed and permanent dentition; (3) Intervention: 'Routine dental check': 'clinical examination, advice, charting (including monitoring of periodontal status) and report' as defined in the NHS Executive General Dental Service Statement of Dental Remuneration; (4) Comparator: no routine dental check or routine dental check(s) of different recall frequency; (5) Primary outcomes: caries, periodontal disease, quality of life, oral cancer.

Results Twenty eight studies were identified for the review. Studies were poorly reported and clinically heterogenous which restricted comparison between studies and limited generalisability to the UK situation. There was no consistency across multiple studies in the direction of effect of different dental check frequencies on measures of caries in deciduous mixed or permanent dentition, periodontal disease or oral cancer in permanent dentition. No studies were identified linking empirical measures of quality of life associated with oral health and dental check frequency.

Conclusions There is no existing high quality evidence to support or refute the practice of encouraging six-monthly dental checks in adults and children.
\end{abstract}

Oral health can be defined as a general state of well-being as a result of a healthy and functioning mucosae, gingivae and dentition. General oral health is improving in most industrial countries in both children and adults. ${ }^{1,2}$ In the UK, despite an increasing incidence of oral cancer in adults and static levels of periodontal

${ }^{1 *}$ Clinical Research Fellow, ${ }^{3}$ Information Specialist, ${ }^{5}$ Senior Lecturer in Public Health \&t Epidemiology, West Midlands Health Technology Assessment Collaboration, Department of Public Health \& Epidemiology, University of Birmingham; ${ }^{2}$ Consultant in Dental Public Health Rowley Regis and Tipton PCT, Kingston House, 438 High Street, West Bromwich, B70 9LD; ${ }^{4}$ Consultant in Dental Public Health, Heron House, 120 Grove Road, Fenton, Stoke on Trent, Staffordshire ST4 4LX

${ }^{*}$ Correspondence to: Dr Clare Davenport, Department of Public Health and Epidemiology, University of Birmingham, Edgbaston, Birmingham B15 2T

E-mail:C.F.Davenport@bham.ac.uk

\section{Refereed paper}

Received 28.08.02; Accepted 03.03.03

doi:10.1038/sj.bdj.4810337

๑) British Dental Journal 2003; 195: 87-98 disease in children there has been a marked observed improvement in general oral health (experience of periodontal disease, caries and tooth loss in adults and caries in children) over the past three decades. $^{3-7}$ However important variations in oral health exist, reflecting a complex interaction of modifying factors for the development and management of oral disease. These modifying factors include age, diet, socio-economic status, ethnicity, tobacco use, fluoride use, dental attendance and clinician performance. ${ }^{8-13}$

Six-monthly dental checks have been customary in the General Dental Service in the United Kingdom since the inception of the NHS. NHS regulations recognise this practice and although the NHS does not explicitly recommend a specific dental check recall frequency, current remuneration policy provides incentives for regular recall of individuals. Dental practitioners can be remunerated for performing six-monthly checks $^{14}$ and registration with an NHS dentist lapses with greater than a 15-month gap between visits. ${ }^{15}$

The improvement in oral health, accompanied by a greater understanding of risk factors for disease progression, has raised the question whether dental check recall intervals should be adjusted to reflect current oral health needs more closely in order to optimise the clinical and cost-effectiveness of dental checks. ${ }^{9-11,16}$ Most debate has focused on whether the traditional practice of a sixmonthly 'blanket' recall which currently exists in the UK should be lengthened.

Possible disadvantages of lengthening recall intervals include moving away from a preventative approach resulting in more serious sequelae of caries (bigger restorations and an increased number of extractions) and a loss of opportunity to arrest the development of periodontal disease by encouraging improved personal oral hygiene and initiating appropriate treatment. ${ }^{10}$ There may also be risks to the development of patientprofessional rapport and a loss of the potential for positive behaviour change, (advice on smoking and diet) that dentist-patient encounters provide. Possible advantages of lengthening recall intervals are a reduction in costs for both patients and the NHS and a reduction in inappropriate treatment - (mainly fewer numbers of fillings) as a result of allowing the natural arrest or regression of caries lesions in enamel and less exposure of patients to unreliable diagnosis of caries..$^{9,15}$

Researchers have attempted to define an optimal (cost-effective) dental check recall frequency in caries based on bitewing 
radiological diagnosis of caries and modelling of average disease progression, ${ }^{8,12,17}$ restoration therapy longevity ${ }^{8}$ and risk of caries. ${ }^{13}$

A number of reviews have considered the effectiveness of dental checks of differing frequencies ${ }^{9,10}$ but none of these have been conducted using systematic methods and therefore likely to be subject to bias and not to be comprehensive. Therefore it remains uncertain as to what might be the optimal recall frequency for clinical examination for multiple types of oral disease, in deciduous, mixed and permanent dentition and taking into account a range of modifying factors for disease progression.

This review aims to systematically review the evidence for the effectiveness of routine dental checks in adults and children; specifically whether effectiveness is altered by the frequency of the dental check interval.

\section{METHODS}

\section{Search strategy}

A number of electronic bibliographic databases (Cochrane Library, MEDLINE; EMBASE and the National Research Register) were searched for randomised/non-randomised controlled trials and observational studies. The search took place up to March 2001 and there were no restrictions by language. Search terms included various configurations of a range of text words eg dental visits, dental frequency, dental recall and the MESH terms preventive dentistry, dental caries, tooth diseases and oral health. Search filters (ie pre-defined groupings of text and MeSH terms) to identify trials, cohort and case control studies were included where appropriate.

Citation lists from included references were examined in order to identify additional relevant studies. In addition we contacted experts directly and via relevant internet sites. These included the Faculties of General Dental Practitioners and Dental Surgery of the Royal College of Surgeons, England, the Scottish Dental Practice Board, the Dental Practice Board for England and Wales, (Eastbourne), the Central Services Agency, (Dental Information) Northern Ireland, Stakes National Research and Development Centre for Welfare and Health, Helsinki, Finland, the Dental Health Service Research Units at Sheffield and Dundee Universities and the Cochrane Oral Health Group specialised register of controlled trials.

\section{Study selection}

Identified studies were initially screened by one reviewer (CD) who excluded articles clearly of no relevance to the review. For remaining articles the following inclusion and exclusion criteria were applied by two independent reviewers (CD and KE).

Study design: Any comparative design.

Population: Children ( $<18$ years) and/or adults ( $\geq 18$ years) representing deciduous, mixed and permanent dentitions.

Intervention: Routine dental check as defined by the NHS in its dental remuneration statement: ${ }^{14}$ 'Clinical examination, advice, charting (including monitoring of periodontal status) and report'. In practice it proved impractical to strictly apply this criteria as studies invariably provided insufficient specific detail about the intervention. Studies were therefore included if the intervention was identified either as a 'dental check' or a 'dental check' followed by treatment initiated by the check.

Comparator: No routine dental check or routine dental check(s) of different frequency.

Outcomes: Caries, tooth loss, periodontal disease, quality of life, oral cancer.

Given the change in the epidemiology of caries ${ }^{1,2,3-7}$ and in dental treatment practice $^{10}$ (a previous greater emphasis on a restorative rather than a preventative care philosophy) in the developed world since 1980, studies were excluded if the data of data collection took place prior to this date.

\section{Assessment and reporting of study quality}

The quality of included studies was assessed by one reviewer (CD) and for a random 50\% of included studies by another reviewer independently (KE) using items from specific appraisal checklists appropriate to the study design ie controlled trial, cohort (prospective and retrospective), case control, cross sectional and case series. ${ }^{18}$ Some topic specific items were added to these checklists, for example measurement of oral health status at baseline and social class as a prompt to specific confounding variables.

Judgements on the appropriateness of statistical analysis were further independently checked by a statistician (RT). Study quality was compared across studies using the categories of selection bias and confounding, external validity, performance bias, attrition bias and appropriateness of statistical analysis (Appendix 1). A conservative approach was taken and if a feature was not reported it was assumed to be absent. Where a study did not meet a quality criterion, a judgement was made as to whether this constituted a minor or major threat to the validity of the study. These judgements were based on the context of this review. For example, a study with a non randomised design allocating individuals to differing groups of dental check frequency which provided no evidence of balance in the baseline characteristics of the groups has the potential for considerable selection bias and therefore judged as a major threat to validity. On the other hand, given the nature of the outcomes being assessed in this review, a study without blinding of outcome assessment would be unlikely to be a major source of assessment bias and therefore judged to be a minor threat to validity. This process was undertaken by two reviewers (CD and RT) independently.

\section{Data extraction}

Data extraction was undertaken using a pre-designed data extraction form by one reviewer (CD) and for a random 50\% of included studies by another reviewer independently (KE). Where information was missing or further clarity was needed, authors were contacted (100\% of studies). Replies were received from five out of a total of 24 authors.

To ensure continuity, one reviewer (CD) was responsible for the initial screening of abstracts, selecting papers based on the review inclusion/exclusion criteria, assessing the quality of included papers and making judgements about potential threats to validity. Overall agreement between independent reviewers (CD, KE and RT) for study inclusion decisions, quality assessment and data extraction was good (at least 70\%) and all disagreements were resolved by discussion without recourse to a third party.

\section{Data synthesis}

Data synthesis using meta-analysis was not deemed appropriate due to the marked heterogeneity between studies arising most importantly from apparent differences in the intervention under investigation, poor quality of reporting and the wide range of outcome measures used for each of the primary outcomes being considered by the review (Table 1).

Instead a method of vote-counting was employed - the results of each study were summarised as either positive: a study that reports a statistically significant (ie $P \leq 0.05$ ) increase in outcome with a decrease in dental check frequency; negative: a study that reports a statistically significant decrease in outcome with a decrease in dental check frequency; or neutral: a study that reports a non statistically significant difference in outcome with a decrease in dental check frequency, fails to report a statistical significance or reports a bi-directional outcome.

In order to assess the impact of study quality on the findings a sensitivity analysis exercise was undertaken. Studies with one or more major threats to validity were excluded from the 
vote-counting exercise in order that the results of those studies least subject to bias and confounding could be considered alone (Table 3).

\section{RESULTS}

\section{Number of studies}

A total of 2,596 potentially relevant citations and abstracts were initially identified of which 68 were formally assessed for inclusion. Twenty four papers reporting 28 studies were finally included in the analysis of which 25 reported outcomes relating to caries, nine reported outcomes relating to periodontal disease and two reported outcomes relating to oral cancer. No studies were identified investigating the relationship between dental check frequency and empirical measures of quality of life associated with oral health. Thirty eight studies were excluded on the basis of full publications. In 17 studies, dental checks were not the subject of the study; in three studies comparison groups were not subject to dental checks of different frequencies; in five studies the dental check offered to comparison groups was different in content (apart from frequency); in seven studies no primary or secondary review outcomes were reported; in five studies the date of data collection was prior to 1980 and one study was a descriptive review. Figure 1 summarises the selection and exclusion process.

\section{Characteristics of included studies}

Table 1 outlines key characteristics of studies included in the review. Studies were generally poorly reported particularly with respect to details of the intervention under investigation.

Six of the 28 studies were undertaken in a UK setting, 18 elsewhere in Europe and one each in Canada, the USA, Australia and Hong Kong.
In only two studies ${ }^{30,31}$ could it be assumed that the intervention under study was comparable specifically to the dental check as it currently applies in the UK and as outlined in the NHS Executive General Dental Service Statement of Remuneration. Seventeen studies investigated the relationship between long-term dental check behaviour pattern and oral health outcomes 19,20,23(a),23(b)24,25,28,29,31,32,34,35(a),35(b),35(c),36,38,39 and 12 studies investigated the relationship between recent dental check behaviour and oral health outcomes. ${ }^{21,22,23(c), 26,27,30,31,33,37,40,41,42}$ Only 11 studies measured the intervention objectively either by following individuals prospectively or by retrospectively checking dental health records. ${ }^{23(a), 23(b), 23(c), 28,30,33,34,37,40,41,42}$ Although outcomes were measured objectively in the majority of studies the type of outcome measure used varied considerably limiting comparison between studies. In one study ${ }^{30}$ the length of follow up was less than two years - a period that was judged inadequate for the outcomes (caries) being considered. ${ }^{8,12,17}$

\section{Quality assessment}

Included studies comprised three controlled trials, three prospective cohort studies, three retrospective cohort studies, 17 cross sectional studies and two retrospective case series.

Table 2 summarises the main threats to validity arising from the execution of studies and data analysis. The frequency of 'unknown' responses illustrates the extent of poor reporting in studies.

The major threat to validity identified in the studies in this review was associated with an imbalance in patient characteristics across comparison groups. In three studies ${ }^{23(a), 23(b), 30}$ there was evidence of such imbalance and therefore considerable potential

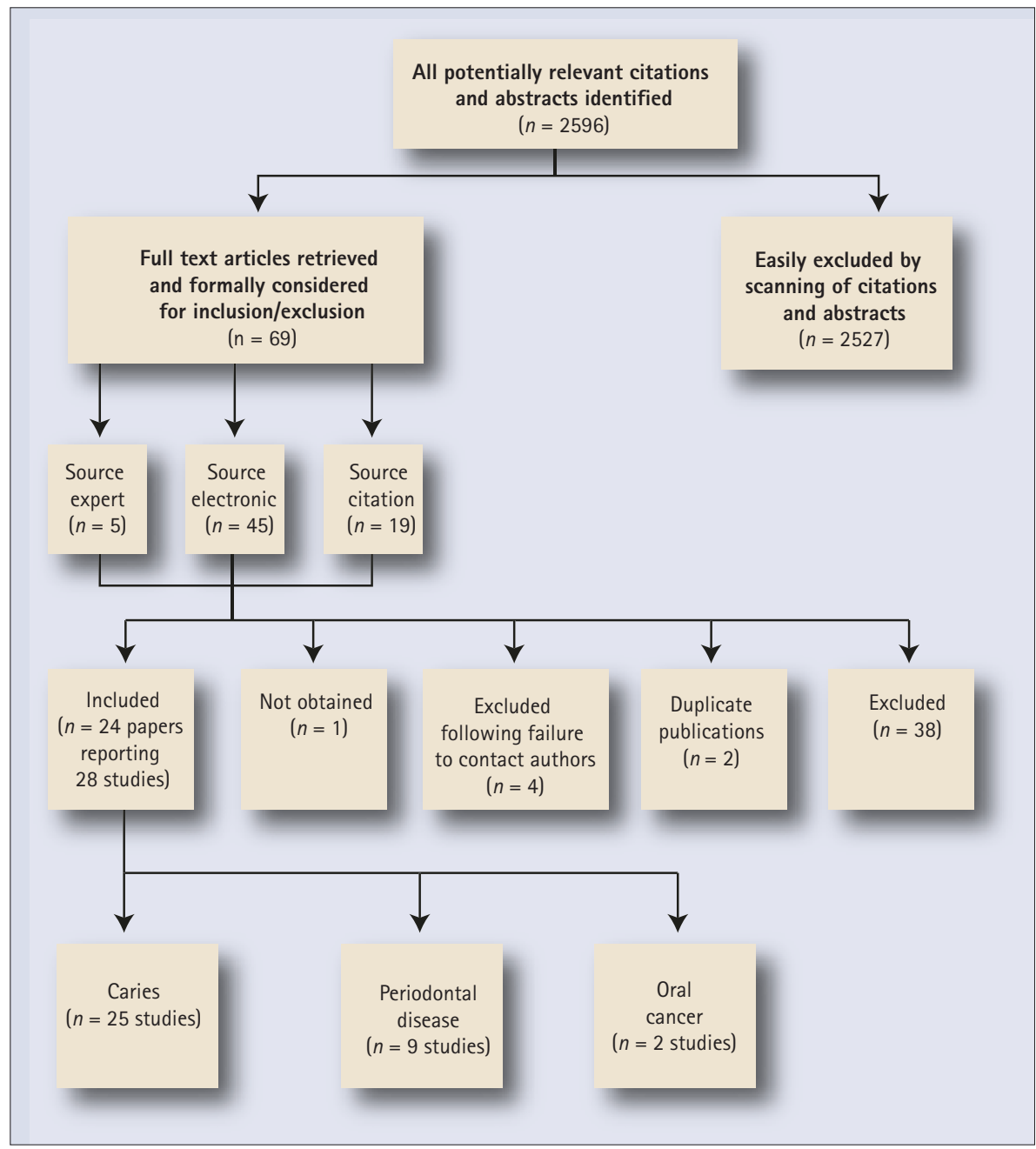


for confounding. In an additional six studies ${ }^{25,32,34,38,41,42}$ patient characteristics were not reported in enough detail to allow assessment of similarity between comparison groups at baseline. Although multivariate statistical methods can be used to adjust for differences in characteristics, none of the nine studies reported such methods.

Two studies ${ }^{33,42}$ reported losses to follow up in excess of $20 \%$ which was considered to introduce attrition bias to such a level that it may be associated with a major threat to validity.

Although a number of studies failed to report outcome results using measures of variance, their methods of statistical analysis were appropriate and therefore not judged as a threat to validity. Similarly, the five studies which failed to report eligibility criteria may influence the external validity and generalisability of the study findings but do not pose a threat to internal validity.

Overall 28/28 (100\%) of studies were judged to have a minor or major threat to validity arising from selection bias and confounding, 11/28 (39\%) arising from problems with external validity, $24 / 28(86 \%)$ arising from performance bias, 5/28 (18\%) arising from attrition bias and 18/28 (64\%) arising from inappropriate statistical analysis. Ten of the total 28 included studies (36\%) were judged to have a major threat to validity on the basis of one criterion or more.

\section{Outcomes}

Table 3 summarises the results of the 28 included studies reporting the relationship between decreasing dental check frequency and caries, periodontal disease and oral cancer. Tests of statistical significance were not performed and could not be calculated by the review team for all or part of the reported results of nine out of a total of 28 included studies. ${ }^{23(a), 23(b), 23(c), 31,33,35(a), 35(b), 35(c), 37 ~}$

\section{Caries}

Deciduous dentition

A total of three studies in deciduous dentition investigated the relationship between dental check frequency and the outcomes 'decayed teeth' and 'decay experience' (dmft). All studies were classed as 'neutral'; in other words the studies either demonstrated no significant association between dental check frequency and the outcome under investigation, did not report tests of statistical significance or demonstrated a statistically significant bi-directional effect. No studies were identified investigating the relationship between dental check frequency and the outcomes 'filled teeth' or 'missing teeth' in deciduous dentition.

\section{Mixed deciduous and permanent dentition}

Three studies in mixed deciduous and permanent dentition investigating the relationship between decay and frequency of dental checks demonstrated conflicting results. Two studies were classified as 'neutral'. One study reported a significant increase in the number of deep cavities with a decrease in dental check frequency.

One study investigating the relationship between dental check frequency and fillings demonstrated a significant reduction in the number of fillings in individuals with dental check frequencies individualised by a dental practitioner on the basis of caries risk compared with individuals attending $\geq$ every $12 / 12$ under a blanket recall policy. One study reported no significant association between DMFT and frequency of dental checks. No studies were identified investigating the relationship between dental check frequency and the outcome 'missing teeth'.

\section{Permanent dentition}

Fifteen studies investigating the relationship between dental check frequency and decay demonstrated conflicting results. Eight studies demonstrated a significant increase in decay with a decrease in dental check frequency whilst seven studies were classified as 'neutral'. No studies reported a decrease in decay with a decrease in dental check frequency.

Nine studies investigating the relationship between dental check frequency and filled teeth demonstrated conflicting results. Five studies reported a significant decrease in fillings with a decrease in dental check frequency whilst four studies were classified as 'neutral'. No studies reported an increase in fillings with a decrease in dental check frequency.

Sixteen studies investigating the relationship between dental check frequency and missing teeth in permanent dentition demonstrated conflicting results. Eight studies reported a significant increase in missing teeth with a decrease in dental check frequency whilst eight studies were classified as 'neutral'. No studies reported a decrease in missing teeth with a decrease in dental check frequency.

Eleven studies investigating the relationship between dental check frequency and DMFT produced conflicting results. Two studies reported a significant increase in DMFT with a decrease in dental check frequency, two studies reported a significant decrease in DMFT with a decrease in dental check frequency and seven studies were classified as 'neutral'.

\section{Periodontal disease}

No studies were identified investigating the relationship between dental check frequency and periodontal outcomes in deciduous and mixed dentition.

Six studies investigating the relationship between dental check frequency and probing depth or presence of pockets produced conflicting results. Two studies demonstrated a significant increase in probing depth with a decrease in dental check frequency whilst four studies were classified as neutral. For the outcome measures bleeding, presence of plaque/calculus, bone score, gingivitis and periodontal health, all studies were classified as neutral.

\section{Oral cancer}

Two studies investigating the relationship between oral cancer and dental check frequency were classified as 'neutral'. One study demonstrated a significant relationship between time since last dental check and tumour size and stage at diagnosis but it remains unclear from the analysis as to whether there is a consistent (or linear) trend in outcome with decreasing dental check frequency. One study found no significant relationship between the presence or absence of a cancerous or pre-cancerous lesion at examination and time since last dental check $(\leq 12 / 12$ to $>12 / 12)$.

\section{Sensitivity analysis}

It is hypothesised from empirical research ${ }^{43}$ that studies of poor methodological quality would tend to overestimate the effect of an intervention ie would be more likely to result in either a significant increase or a significant decrease in outcome when comparing differing dental check frequencies. This did not appear to be the case for any of the primary outcomes being investigated in this review and therefore suggests that the results are robust to variations in the quality of included studies (Table 3).

\section{DISCUSSION}

The aim of this review was to assess the relative effectiveness of routine dental checks of different recall frequencies in adults and children.

Twenty eight studies met the inclusion criteria of this review.

A single study investigating the relationship between dental check frequency and decay in mixed dentition demonstrated an increase in decay with a decrease in dental check frequency. A further single study investigating the relationship between dental 
Table 1 Key characteristics of included studies

\begin{tabular}{|c|c|c|c|c|c|}
\hline \multirow[t]{2}{*}{$\begin{array}{l}\text { AUTHORS } \\
\text { \& COUNTRY }\end{array}$} & \multirow{2}{*}{$\begin{array}{l}\text {-Date of data } \\
\text { collection } \\
\text {-Follow up }\end{array}$} & \multirow{2}{*}{$\begin{array}{l}\text { POPULATION } \\
\text { CHARACTERISTICS } \\
\text {-'N' } \\
\text {-Dentition } \\
\text { (deciduous, mixed, } \\
\text { permanent) }\end{array}$} & \multicolumn{2}{|c|}{$\begin{array}{l}\text { INTERVENTION UNDER } \\
\text { STUDY }\end{array}$} & \multirow[t]{2}{*}{$\begin{array}{l}\text { OUTCOMES } \\
\text { REPORTED }\end{array}$} \\
\hline & & & $\begin{array}{l}\text { Frequencies } \\
\text { compared } \\
\text { (most frequent } \\
\text { and least } \\
\text { frequent) }\end{array}$ & Type & \\
\hline $\begin{array}{l}\text { Ambjornsen, } \\
1986^{19} \\
\text { Norway }\end{array}$ & $\begin{array}{l}-1979-80 \\
\text {-Not } \\
\text { applicable }\end{array}$ & $\begin{array}{l}\text {-159 } \\
\text {-Deciduous } \\
\text {-Mixed } \\
\text {-Permanent }\end{array}$ & $\begin{array}{l}\text { Dental check: } \\
\geq \text { every } 12 / 12 \\
\text { (regular)' } \\
\text { 'v' } \\
\text { < every } 12 / 12 \\
\text { (irregular) }\end{array}$ & $\begin{array}{l}\text { Check } \\
\text { and } \\
\text { treat }^{+}\end{array}$ & $\begin{array}{l}\text { Mean DMFT } \\
\text { Mean DT } \\
\text { Mean MT } \\
\text { Mean FT }\end{array}$ \\
\hline $\begin{array}{l}\text { Bjertness } \\
\text { et al, } 1986^{20} \\
\text { Norway }\end{array}$ & $\begin{array}{l}\text {-1984 } \\
\text {-Not } \\
\text { applicable }\end{array}$ & $\begin{array}{l}\text {-144 } \\
\text {-Permanent }\end{array}$ & 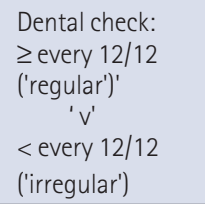 & $\begin{array}{l}\text { Check } \\
\text { and } \\
\text { treat }^{+}\end{array}$ & $\begin{array}{l}\text { Mean DMFS } \\
\text { Mean DS and } \\
\text { DFS } \\
\text { Mean FS }\end{array}$ \\
\hline $\begin{array}{l}\text { Halling and } \\
\text { Bjorn. } \\
1987^{21} \\
\text { Sweden }\end{array}$ & $\begin{array}{l}-1980 \\
\text {-Not } \\
\text { applicable }\end{array}$ & $\begin{array}{l}-542 \\
\text {-Permanent }\end{array}$ & $\begin{array}{l}\text { Last dental } \\
\text { check: } \\
\leq 12 / 12 \text { ago } \\
\quad \text { to } \\
\geq 24 / 12 \text { ago }\end{array}$ & $\begin{array}{l}\text { Check } \\
\text { and } \\
\text { treat }^{\dagger}\end{array}$ & $\begin{array}{l}\text { Mean number of } \\
\text { teeth. } \\
\text { Mean bone score }\end{array}$ \\
\hline $\begin{array}{l}\text { Jullien et al, } \\
1995^{22} \\
\text { UK }\end{array}$ & $\begin{array}{l}\text {-Not stated } \\
\text {-Not } \\
\text { applicable }\end{array}$ & $\begin{array}{l}-2,027 \\
\text {-Permanent }\end{array}$ & $\begin{array}{l}\text { Time since last } \\
\text { dental check: } \\
\leq 12 / 12 \\
\quad \text { to } \\
>12 / 12\end{array}$ & $\begin{array}{l}\text { Check* }^{*} \\
\text { and } \\
\text { treat }^{+}\end{array}$ & $\begin{array}{l}\text { Proportion of } \\
\text { sample with a } \\
\text { diagnosis of oral } \\
\text { cancer/pre-cancer. }\end{array}$ \\
\hline $\begin{array}{l}\text { Ketomaki } \\
\text { and Luoma, } \\
1993 \text { 23(a) } \\
\text { Finland }\end{array}$ & $\begin{array}{l}-1979-1985 \\
-6 \text { years }\end{array}$ & $\begin{array}{l}\text {-1,215: Permanent } \\
\text {-5,850: Deciduous }\end{array}$ & $\begin{array}{l}\text { Dental check: } \\
\text { every } 6 / 12 \\
\quad \text { to } \\
\leq \text { every } 37 / 12\end{array}$ & Check & $\begin{array}{l}\text { Proportion of } \\
\text { sample with caries } \\
\text { lesions index } \\
\text { increment }\end{array}$ \\
\hline $\begin{array}{l}\text { Ketomaki } \\
\text { and Luoma, } \\
1993^{23(b)} \\
\text { Finland }\end{array}$ & $\begin{array}{l}-1979-1985 \\
-6 \text { years }\end{array}$ & $\begin{array}{l}\text {-2,353: Permanent } \\
\text {-901: Deciduous }\end{array}$ & $\begin{array}{l}\text { Dental check: } \\
\geq \text { every } 12 / 12 \\
\quad \text { to } \\
\text { every } 72 / 12\end{array}$ & Check & $\begin{array}{l}\text { Mean change dmft } \\
\text { and DMFT/6 years. } \\
\text { Mean change dmft } \\
\text { and DMFT/yr. }\end{array}$ \\
\hline $\begin{array}{l}\text { Ketomaki } \\
\text { and Luoma, } \\
1993 \text { 23(c) } \\
\text { Finland }\end{array}$ & $\begin{array}{l}-1988-1990 \\
-2 \text { years }\end{array}$ & $\begin{array}{l}-1177 \\
\text {-Mixed }\end{array}$ & $\begin{array}{l}\text { Dental check: } \\
\text { every } 12 / 12 \\
\text { 'v' } \\
\text { Dental check } \\
\text { frequency } \\
\text { individualised } \\
\text { according to } \\
\text { caries risk; range } \\
\text { 3-24/12. }\end{array}$ & Check & $\begin{array}{l}\text { Mean change in dt } \\
\text { and DT index } \\
\text { /person/ } 3 \text { years. }\end{array}$ \\
\hline $\begin{array}{l}\text { King et al, } \\
1986^{24} \\
\text { Hong Kong }\end{array}$ & $\begin{array}{l}\text {-Not stated } \\
\text {-Not } \\
\text { applicable }\end{array}$ & $\begin{array}{l}-662 \\
\text {-Permanent }\end{array}$ & $\begin{array}{l}\text { Proportion of } \\
\text { sample never had } \\
\text { a dental check. }\end{array}$ & $\begin{array}{l}\text { Check } \\
\text { and } \\
\text { treat }^{+}\end{array}$ & $\begin{array}{l}\text { Mean DMFT } \\
\text { Mean DT } \\
\text { Mean missing } \\
\text { teeth } \\
\text { Mean FT. }\end{array}$ \\
\hline $\begin{array}{l}\text { Lie and } \\
\text { Mellingen, } \\
1988^{25} \\
\text { Sweden }\end{array}$ & $\begin{array}{l}\text {-Not stated } \\
\text {-Not clear }\end{array}$ & $\begin{array}{l}-123 \\
\text {-Permanent }\end{array}$ & $\begin{array}{l}\text { Dental check: } \\
\text { > every } 12 / 12 \\
\text { (regular) } \\
\quad \text { to } \\
\text { < every } 24 / 12 \text { or } \\
\text { only in } \\
\text { emergencies }\end{array}$ & $\begin{array}{l}\text { Check } \\
\text { and } \\
\text { treat }^{+}\end{array}$ & $\begin{array}{l}\text { Mean missing } \\
\text { teeth (not } \\
\text { including wisdom } \\
\text { teeth) } \\
\text { Mean gingival } \\
\text { sites with bleeding } \\
\text { on probing. } \\
\text { Mean probing } \\
\text { depth. } \\
\text { Mean bone score. } \\
\text { Mean individuals } \\
\text { with stainable } \\
\text { plaque. }\end{array}$ \\
\hline
\end{tabular}




\begin{tabular}{|c|c|c|c|c|c|}
\hline \multirow[t]{2}{*}{$\begin{array}{l}\text { AUTHORS } \\
\text { \& COUNTRY }\end{array}$} & \multirow{2}{*}{$\begin{array}{l}\text {-Date of data } \\
\text { collection } \\
\text {-Follow up }\end{array}$} & \multirow{2}{*}{$\begin{array}{l}\text { POPULATION } \\
\text { CHARACTERISTICS } \\
\text {-'N' } \\
\text {-Dentition } \\
\text { (Deciduous, Mixed, } \\
\text { Permanent) }\end{array}$} & \multicolumn{2}{|c|}{$\begin{array}{l}\text { INTERVENTION UNDER } \\
\text { STUDY }\end{array}$} & \multirow[t]{2}{*}{$\begin{array}{l}\text { OUTCOMES } \\
\text { REPORTED } \\
\end{array}$} \\
\hline & & & $\begin{array}{l}\text { Frequencies } \\
\text { compared } \\
\text { (most frequent } \\
\text { and least } \\
\text { frequent) }\end{array}$ & Type & \\
\hline $\begin{array}{l}\text { Lissau et al, } \\
1990^{26} \\
\text { Denmark }\end{array}$ & $\begin{array}{l}-1985 \\
\text {-Not } \\
\text { applicable }\end{array}$ & $\begin{array}{l}\text {-756 } \\
\text {-Permanent }\end{array}$ & $\begin{array}{l}\text { Dental check: } \\
>2 \text { times in last } \\
36 / 12 \text { (regular) } \\
\text { ' } v \text { ' } \\
\leq 2 \text { times in last } \\
36 / 12 \text { (irregular) }\end{array}$ & $\begin{array}{l}\text { Check } \\
\text { and } \\
\text { treat }^{\dagger}\end{array}$ & $\begin{array}{l}\text { Mean bleeding } \\
\text { index. } \\
\text { Mean pocket } \\
\text { index. } \\
\text { Mean calculus } \\
\text { index. }\end{array}$ \\
\hline $\begin{array}{l}\text { Locker et al., } \\
1989^{27} \\
\text { Canada }\end{array}$ & $\begin{array}{l}-1987 \\
\text {-Not } \\
\text { applicable }\end{array}$ & $\begin{array}{l}-247 \\
\text {-Permanent }\end{array}$ & $\begin{array}{c}\geq 1 \text { dental check } \\
\text { in last } 12 / 12 \\
\text { ' } v^{\prime} \\
<1 \text { dental check } \\
\text { in last } 12 / 12\end{array}$ & $\begin{array}{l}\text { Check } \\
\text { and } \\
\text { treat }^{\dagger}\end{array}$ & $\begin{array}{l}\text { Association } \\
\text { between root } \\
\text { caries (DFS and } \\
\text { DS) and dental } \\
\text { check frequency. }\end{array}$ \\
\hline $\begin{array}{l}\text { Lunder, } \\
1994^{28} \\
\text { Norway }\end{array}$ & $\begin{array}{l}-1986-1993 \\
-6 \text { years }\end{array}$ & $\begin{array}{l}-45 \\
- \text { Mixed }\end{array}$ & $\begin{array}{l}\text { Dental check: } \\
\text { every } 12 / 12 \\
\text { ' } v \text { ' } \\
\text { every } 18 / 12\end{array}$ & Check & $\begin{array}{l}\text { Mean DMFS } \\
\text { increment } / 6 \text { years. } \\
\text { Increment number } \\
\text { of deep cavities } / 6 \text { years. }\end{array}$ \\
\hline $\begin{array}{l}\text { Marques et al, } \\
199429 \\
\text { Oslo, } \\
\text { Norway } \\
\text { \&t } \\
\text { Porto, } \\
\text { Portugal }\end{array}$ & $\begin{array}{l}\text {-1984\&t1990 } \\
\text {-Not } \\
\text { applicable }\end{array}$ & $\begin{array}{l}\text { - Norway: } 200 \\
\text { Portugal: } 322 \\
\text { - Permanent }\end{array}$ & $\begin{array}{l}\text { Dental check: } \\
\text { zevery } 12 / 12 \\
\text { ('regular') } \\
\quad \text { 'v' } \\
\text { < every } 12 / 12 \\
\text { ('irregular') }\end{array}$ & $\begin{array}{l}\text { Check } \\
\text { and } \\
\text { treat }^{\dagger}\end{array}$ & $\begin{array}{l}\text { Mean DMFT } \\
\text { Mean DS } \\
\text { Mean missing } \\
\text { teeth } \\
\text { Mean FS. }\end{array}$ \\
\hline $\begin{array}{l}\text { Morrant et al, } \\
1995^{30} \\
\text { England }\end{array}$ & $\begin{array}{l}\text {-Not stated } \\
-1 \mathrm{yr}\end{array}$ & $\begin{array}{l}-175 \\
\text {-Permanent }\end{array}$ & $\begin{array}{l}\text { Attended for an } \\
\text { asymptomatic } \\
\text { dental check } \\
\leq 12 / 12 \text { ago } \\
\text { ' } v \text { ' } \\
\text { Did not attend for } \\
\text { an asymptomatic } \\
\text { dental check } \\
\leq 12 / 12 \text { ago }\end{array}$ & Check $^{*}$ & $\begin{array}{l}\text { Mean DMFT } \\
\text { Mean DT } \\
\text { Mean missing } \\
\text { teeth } \\
\text { Mean FS } \\
\text { Mean individuals } \\
\text { with presence of } \\
\text { plaque. }\end{array}$ \\
\hline $\begin{array}{l}\text { Murray, } \\
1996^{31} \\
\text { UK }\end{array}$ & $\begin{array}{l}\text {-1988\&1993 } \\
\text {-Not } \\
\text { applicable }\end{array}$ & $\begin{array}{l}-1,060: \underline{\text { Adult }} \\
-1,980: \underline{\text { Child }} \\
\text { - Permanent }\end{array}$ & $\begin{array}{l}\text { Adult: } \\
\text {-Always regular } \\
\text { dental checks } \\
\quad \text { to } \\
\text {-Never had } \\
\text { regular dental } \\
\text { checks } \\
\text { Children: } \\
\text { Last dental check } \\
\leq 6 / 12 \text { ago } \\
\text { to } \\
\text { Dental check only } \\
\text { if experiencing } \\
\text { problems }\end{array}$ & Check $^{*}$ & $\begin{array}{l}\text { Mean DMFT } \\
\text { Mean DT } \\
\text { Mean missing } \\
\text { teeth } \\
\text { Mean FT }\end{array}$ \\
\hline $\begin{array}{l}\text { Nordstrom et al, } \\
1998^{32} \\
\text { Sweden }\end{array}$ & $\begin{array}{l}-1980-1990 \\
-10 \text { years }\end{array}$ & $\begin{array}{l}-180 \\
\text { - Permanent }\end{array}$ & $\begin{array}{c}\text { Dental check: } \\
\geq \text { every } 12 / 12 \\
\text { ' } v \text { ' } \\
\text { Never/only if } \\
\text { symptomatic }\end{array}$ & $\begin{array}{l}\text { Check } \\
\text { and } \\
\text { treat }^{\dagger}\end{array}$ & $\begin{array}{l}\text { Proportion sample } \\
\text { with DMFT > } 0 \text {. } \\
\text { Proportion sample } \\
\text { with DT. } \\
\text { Total number of } \\
\text { teeth in sample. } \\
\text { Proportion sample } \\
\text { With FT } \\
\text { Proportion of } \\
\text { sample with } \\
\text { bleeding surfaces. } \\
\text { Proportion of sample } \\
\text { with attachment } \\
\text { level }>3 \mathrm{~mm}\end{array}$ \\
\hline
\end{tabular}




\begin{tabular}{|c|c|c|c|c|c|}
\hline \multirow[t]{2}{*}{$\begin{array}{l}\text { AUTHORS } \\
\text { AND COUNTRY }\end{array}$} & \multirow{2}{*}{$\begin{array}{l}\text {-Date of data } \\
\text { collection } \\
\text {-Follow up }\end{array}$} & \multirow{2}{*}{$\begin{array}{l}\text { POPULATION } \\
\text { CHARACTERISTICS } \\
\text {-'N' } \\
\text {-Dentition } \\
\text { (Deciduous, Mixed, } \\
\text { Permanent) }\end{array}$} & \multicolumn{2}{|c|}{$\begin{array}{l}\text { INTERVENTION UNDER } \\
\text { STUDY }\end{array}$} & \multirow[t]{2}{*}{$\begin{array}{l}\text { OUTCOMES } \\
\text { REPORTED }\end{array}$} \\
\hline & & & $\begin{array}{l}\text { Frequencies } \\
\text { compared } \\
\text { (most frequent } \\
\text { and least } \\
\text { frequent) }\end{array}$ & Type & \\
\hline $\begin{array}{l}\text { Nuttall, } 1984^{33} \\
\text { Scotland }\end{array}$ & $\begin{array}{l}-1978-1983 \\
-5 \text { years }\end{array}$ & $\begin{array}{l}\text {-504 } \\
\text {-Permanent }\end{array}$ & $\begin{array}{l}\text { Dental check: } \\
\geq \text { every } 18 / 12 \\
\text { ('frequent') } \\
\quad \text { ' } v \text { ' } \\
\text { At least one } \\
\text { dental check in } \\
5 \text { years ('infrequent' }\end{array}$ & $\begin{array}{l}\text { Check* }^{*} \\
\text { and } \\
\text { treat }\end{array}$ & $\begin{array}{l}\text { - Average number } \\
\text { of teeth extracted } \\
\text { - Average number } \\
\text { of fillings }\end{array}$ \\
\hline $\begin{array}{l}\text { Nuttall, } 1991^{34} \\
\text { Scotland }\end{array}$ & $\begin{array}{l}-1978-1988 \\
-10 \text { years }\end{array}$ & $\begin{array}{l}-702 \\
\text {-Permanent }\end{array}$ & $\begin{array}{l}\geq 11 \text { dental } \\
\text { checks in } 10 \text { years } \\
\text { to } \\
1 \text { dental check in } \\
10 \text { years }\end{array}$ & $\begin{array}{l}\text { Check }^{*} \\
\text { and } \\
\text { treat }^{+}\end{array}$ & $\begin{array}{l}\text { Number of } \\
\text { individuals } \\
\text { becoming } \\
\text { edentulous / } 10 \text { years. }\end{array}$ \\
\hline $\begin{array}{l}\text { Nyyssonn, } \\
1992 \\
\text { Mini Finland } \\
\text { 35(a) }\end{array}$ & $\begin{array}{l}-1980 \\
- \text { Not } \\
\text { applicable }\end{array}$ & $\begin{array}{l}\text {-Not stated } \\
\text {-Permanent }\end{array}$ & $\begin{array}{l}\text { Dental check: } \\
\geq \text { every } 24 / 12 \\
\quad \text { to } \\
\text { Dental check only } \\
\text { if experiencing } \\
\text { problems }\end{array}$ & $\begin{array}{l}\text { Check } \\
\text { and } \\
\text { treat }^{+}\end{array}$ & $\begin{array}{l}\text { Proportion sample } \\
\text { with any DT. } \\
\text { Mean DT } \\
\text { Mean number of teeth } \\
\text { Proportion sample edentulous. } \\
\text { Proportion of sample with } \\
\text { pocket depth (shallow / deep). } \\
\text { Proportion of sample with } \\
\text { gingivitis. } \\
\text { Proportion of sample without } \\
\text { calculus+gingivitis+ } \\
\text { periodontitis. }\end{array}$ \\
\hline $\begin{array}{l}\text { Nyyssonn, } \\
1992 \\
\text { Jamsa } 35(b) \\
\text { Finland }\end{array}$ & $\begin{array}{l}-1990 \\
\text {-Not } \\
\text { applicable }\end{array}$ & $\begin{array}{l}\text {-Not stated } \\
\text {-Permanent }\end{array}$ & $\begin{array}{l}\text { Dental check: } \\
\geq \text { every } 24 / 12 \\
\quad \text { to } \\
\text { Dental check only } \\
\text { if experiencing } \\
\text { problems }\end{array}$ & $\begin{array}{l}\text { Check } \\
\text { and } \\
\text { treat }^{+}\end{array}$ & $\begin{array}{l}\text { As for: } \\
\text { Nyyssonn, V } 1992 \\
\text { Mini Finland }{ }^{35(a)} \\
\text { above }\end{array}$ \\
\hline $\begin{array}{l}\text { Nyyssonn, } \\
1992 \text { (c) } \\
\text { Varkaus } 35(\mathrm{c}) \\
\text { Finland }\end{array}$ & $\begin{array}{l}-1990 \\
- \text { Not } \\
\text { applicable }\end{array}$ & $\begin{array}{l}\text {-Not stated } \\
\text {-Permanent }\end{array}$ & $\begin{array}{l}\text { Dental check: } \\
\geq \text { every } 24 / 12 \\
\quad \text { to } \\
\text { Dental check only } \\
\text { if experiencing } \\
\text { problems }\end{array}$ & $\begin{array}{l}\text { Check } \\
\text { and } \\
\text { treat }^{+}\end{array}$ & $\begin{array}{l}\text { As for: } \\
\text { Nyyssonn, V } 1992 \\
\text { Mini Finland 35(a) } \\
\text { above }\end{array}$ \\
\hline $\begin{array}{l}\text { Palmqvist et al, } \\
1986^{36} \\
\text { Sweden }\end{array}$ & $\begin{array}{l}\text {-1982 and } 1983 \\
\text {-Not } \\
\text { applicable }\end{array}$ & $\begin{array}{l}-188 \\
\text {-Permanent }\end{array}$ & $\begin{array}{l}\text { 'Regular dental } \\
\text { checks } \\
\text { 'v' } \\
\text { Irregular dental } \\
\text { checks' (includes } \\
\text { previously regular } \\
\text { now sporadic / } \\
\text { emergencies } \\
\text { only) }\end{array}$ & $\begin{array}{l}\text { Check } \\
\text { and } \\
\text { treat }\end{array}$ & $\begin{array}{l}\text { Mean proportion } \\
\text { of DT sample. } \\
\text { Mean number of } \\
\text { remaining teeth in } \\
\text { sample. } \\
\text { Proportion of } \\
\text { sample with } \\
\text { pocket depth } \\
>3 \mathrm{~mm} \text {. }\end{array}$ \\
\hline $\begin{array}{l}\text { Riordan, } \\
1995^{37} \\
\text { Western } \\
\text { Australia }\end{array}$ & $\begin{array}{l}\text {-1980-1994 } \\
\text { (yearly) } \\
\text {-Not } \\
\text { applicable }\end{array}$ & $\begin{array}{l}\text {-Deciduous } \\
\text {-Permanent }\end{array}$ & $\begin{array}{l}\text { Mean frequency } \\
\text { of dental checks/ } \\
\text { year of study: } \\
6.6 / 12 \\
\text { to } \\
12.8 / 12\end{array}$ & Check & $\begin{array}{l}\text { Mean dt. } \\
\text { Mean DMFT }\end{array}$ \\
\hline $\begin{array}{l}\text { Rubright et al, } \\
1996^{38} \\
\text { USA }\end{array}$ & $\begin{array}{l}\text {-1990-1994 } \\
\text {-Not clear }\end{array}$ & $\begin{array}{l}-53 \\
\text {-Permanent }\end{array}$ & $\begin{array}{l}\text { Time since last } \\
\text { dental check: } \\
12 / 12 \\
\quad \text { to } \\
\geq 18 \text { years }\end{array}$ & $\begin{array}{l}\text { Check } \\
\text { and } \\
\text { treat }^{+}\end{array}$ & $\begin{array}{l}\text { Proportion of } \\
\text { sample with } \\
\text { tumours and } \\
\text { stage. }\end{array}$ \\
\hline
\end{tabular}




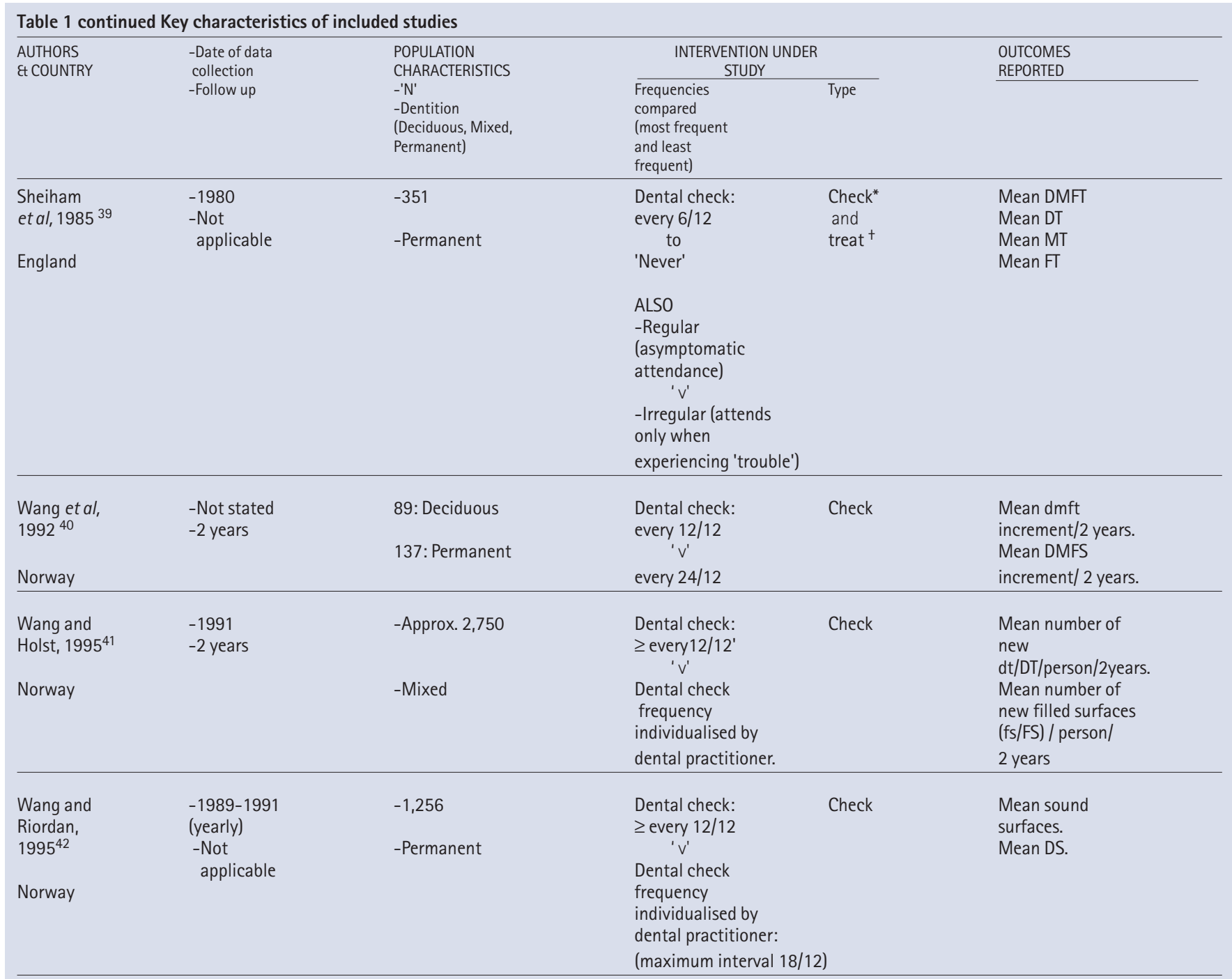

Notes: Check $=$ Dental check was a component of the intervention under investigation.

Check $^{*}=$ Routine dental check as defined by the NHS dental remuneration statement

Treat = Treatment was included as part of the intervention under investigation.

Treat: ${ }^{\dagger}$ Unclear if treatment was part of the intervention under investigation.

DMFT/dmft = Decayed, missing and filled teeth (decay experience).

$\mathrm{DMFS} / \mathrm{dmfs}=$ Decayed, missing and filled surfaces (decay experience)

$\mathrm{DT} / \mathrm{dt}=$ Decayed teeth .

DS/ds = Decayed surfaces

$\mathrm{DFS} / \mathrm{dfs}=$ Decayed and filled surfaces.

$\mathrm{FT} / \mathrm{ft}=$ Filled teeth

$\mathrm{FS} / \mathrm{fs}=$ Filled surfaces.

check frequency and filled teeth in mixed dentition demonstrated a significant reduction in the number of fillings in individuals recalled for dental checks according to an assessment by a dental practitioner compared with individuals recalled at 12 monthly intervals. For all other caries outcomes there was no consistency in the direction of effect of outcomes across multiple studies with decreasing dental check frequency.

With the exception of studies investigating the effect of dental check frequency on probing depth or pockets, for all other periodontal outcomes the effect of changing dental check frequency was neutral.

For oral cancer outcomes two studies demonstrated that decreasing dental check frequency had a neutral effect.

On the basis of these results it can be concluded that there is no existing high quality evidence to support or refute the practice of encouraging six-monthly or any other specific frequency of dental check in adults and children. Furthermore, the included studies were poorly reported and clinically heterogenous which restricted between study comparison and limited generalisability to the UK situation.

\section{Potential limitations of the review \\ Quality of evidence}

A major limitation of this review was the poor quality of evidence. There was a preponderance of studies of cross-sectional design which are particularly prone to selection bias and confounding.

The majority of data collection for studies included in the review occurred during the 1980s which will give rise to 'interference' when interpreting results due to the continuing decline in the incidence of caries since this date.

The evidence available to this review was also poorly reported. Inadequate description of patient characteristics and the intervention under study (the dental check) limits comparison between studies and may influence the synthesised results of these studies. Poor quality studies result in biases that may lead to overestimation 
of an intervention's benefit. ${ }^{43}$ However the fact that sensitivity analysis on study quality did not alter the pattern of results across the majority of outcomes under investigation suggests that variation in the quality of studies included in the review was not the primary reason for the general lack of consistency of outcomes observed across studies.

\section{Definition of intervention}

Eleven out of 28 studies restricted their measurement of dental check frequency to the most recent dental check attendance and only 11 studies measured the intervention objectively either by following individuals prospectively or by retrospectively checking dental health records. There is evidence of inaccuracies in individual reports of dental check attendance ${ }^{44}$ and recent dental check attendance may not be representative of past behaviour. This raises questions about the accuracy and representativeness of the frequencies purportedly under investigation. Similarly studies reporting dental check frequencies based on a population policy of offering dental checks of a certain frequency are not measuring the attendance behaviour of individuals. ${ }^{44}$

Comparison of the evidence reviewed with the current UK situation was limited. Only six of the studies included were conducted in the UK. There was a lack of information on access to and the content of the intervention under study and in only two stud- ies $^{30,31}$ could it be assumed that the intervention under study was comparable specifically to the dental check as it applies in the UK today and as outlined in the NHS Executive General Dental Service Statement of Remuneration. Differences in treatment practices occurring geographically and over time will in particular affect the outcome 'filled teeth' and outcomes associated with periodontal disease.

\section{Synthesis of evidence}

Synthesis of evidence in this review was restricted by clinical heterogeneity. Due to problems defining the intervention under study, the range of dental frequencies studied and the range of outcome measures used, the results were pooled using vote counting rather than meta-analysis. Vote counting has the limitation that it gives equal weight to studies regardless of their size and therefore potentially over- and underestimates the importance of small and large studies respectively. Pooling the results does not reflect important differences between studies whose results are being grouped such as the different frequencies being compared for each single outcome. For example in the investigation of caries in the permanent dentition, dental check frequencies across studies ranged from individuals attending for dental checks $\geq$ every 6 months to individuals who had never had a dental check. It could be postulated that any effect of the frequency of dental checks on the outcomes

Table 2 Quality assessment of included studies (studies judged to have a major threat to validity present are shaded red)

\begin{tabular}{|c|c|c|c|c|c|c|c|c|}
\hline \multirow[t]{3}{*}{ STUDY REFERENCE AND DESIGN } & \multicolumn{8}{|c|}{ CATEGORY AND CRITERIA ( $a, b$ or $c$ ) (See Appendix 1 ) } \\
\hline & \multicolumn{3}{|c|}{$\begin{array}{l}\text { Selection bias and } \\
\text { confounding }\end{array}$} & \multirow[t]{2}{*}{$\begin{array}{l}\text { External } \\
\text { validity }\end{array}$} & \multirow[t]{2}{*}{$\begin{array}{l}\text { Performance } \\
\text { bias }\end{array}$} & \multicolumn{2}{|c|}{$\begin{array}{l}\text { Attrition } \\
\text { bias }\end{array}$} & \multirow{2}{*}{$\begin{array}{l}\text { Appropriate } \\
\text { statistical } \\
\text { analysis }\end{array}$} \\
\hline & a & b & c & & & a & b & \\
\hline Ambjornsen, $1986 .{ }^{19}$ Cross sectional & $n / a$ & $\checkmark$ & $?(\mathrm{~m})$ & $\checkmark$ & $?(\mathrm{~m})$ & $n / a$ & $n / a$ & $\boldsymbol{x}(\mathrm{m})$ \\
\hline Bjertness et al, $1986 .^{20}$ Cross sectional & $n / a$ & $\boldsymbol{x}(\mathrm{m})$ & $?(\mathrm{~m})$ & $\checkmark$ & $?(\mathrm{~m})$ & $n / a$ & $n / a$ & $\boldsymbol{x}(\mathrm{m})$ \\
\hline Halling and Bjorn, $1987 .{ }^{21}$ Cross sectional & $n / a$ & $\boldsymbol{x}(\mathrm{m})$ & $?(\mathrm{~m})$ & $\checkmark$ & $?(\mathrm{~m})$ & $n / a$ & $n / a$ & $\checkmark$ \\
\hline Julien et al, $1995 .{ }^{22}$ Cross sectional & $n / a$ & $\checkmark$ & $?(\mathrm{~m})$ & $\checkmark$ & $?(\mathrm{~m})$ & $n / a$ & n/a & $\boldsymbol{x}(\mathrm{m})$ \\
\hline Ketomaki and Luoma, 1993. ${ }^{23(a)}$ Retrospective cohort & $n / a$ & $x(\mathrm{M})$ & $?(\mathrm{~m})$ & $\boldsymbol{X}(\mathrm{m})$ & $?(\mathrm{~m})$ & $?(\mathrm{~m})$ & $\boldsymbol{X}(\mathrm{m})$ & $\boldsymbol{x}(\mathrm{m})$ \\
\hline Ketomaki and Luoma, 1993. ${ }^{23(b)}$ Retrospective cohort & $n / a$ & $x(M)$ & $?(\mathrm{~m})$ & $\boldsymbol{x}(\mathrm{m})$ & $?(\mathrm{~m})$ & $\checkmark$ & $\boldsymbol{x}(\mathrm{m})$ & $\boldsymbol{x}(\mathrm{m})$ \\
\hline Ketomaki and Luoma, $1993 .{ }^{23(c)}$ Controlled trial & $\boldsymbol{x}(\mathrm{m})$ & $\boldsymbol{x}(\mathrm{m})$ & $\checkmark$ & $\checkmark$ & $?(\mathrm{~m})$ & $\checkmark$ & $\boldsymbol{x}(\mathrm{m})$ & $\boldsymbol{x}(\mathrm{m})$ \\
\hline King et al, $1986 .{ }^{24}$ Cross sectional & $n / a$ & $\boldsymbol{x}(\mathrm{m})$ & $?(\mathrm{~m})$ & $\checkmark$ & $?(\mathrm{~m})$ & $n / a$ & $n / a$ & $\checkmark$ \\
\hline Lie and Mellingen, $1988 .{ }^{25}$ Retrospective case series. & $\mathrm{n} / \mathrm{a}$ & $?(\mathrm{M})$ & $?(\mathrm{~m})$ & $\checkmark$ & $?(\mathrm{~m})$ & $n / a$ & $\mathrm{n} / \mathrm{a}$ & $\checkmark$ \\
\hline Lissau et al, $1990 .{ }^{26}$ Cross sectional & $n / a$ & $\boldsymbol{x}(\mathrm{m})$ & $?(\mathrm{~m})$ & $\checkmark$ & $?(\mathrm{~m})$ & $n / a$ & $n / a$ & $\checkmark$ \\
\hline Locker et al, $1989 .{ }^{27}$ Cross sectional & $n / a$ & $\boldsymbol{x}(\mathrm{m})$ & $?(\mathrm{~m})$ & $\checkmark$ & $?(\mathrm{~m})$ & $n / a$ & $n / a$ & $\boldsymbol{x}(\mathrm{m})$ \\
\hline Lunder, $1994 .{ }^{28}$ Controlled trial & $?(\mathrm{~m})$ & $\boldsymbol{x}(\mathrm{m})$ & $\checkmark$ & $\boldsymbol{X}(\mathrm{m})$ & $?(\mathrm{~m})$ & $\checkmark$ & $\boldsymbol{X}(\mathrm{m})$ & $\checkmark$ \\
\hline Marques et al, $1994 .{ }^{29}$ Cross sectional & $\mathrm{n} / \mathrm{a}$ & $\boldsymbol{x}(\mathrm{m})$ & $?(\mathrm{~m})$ & $\checkmark$ & $?(\mathrm{~m})$ & $n / a$ & $n / a$ & $\checkmark$ \\
\hline Morrant et al, $1995 .{ }^{30}$ Retrospective cohort & $n / a$ & $x(M)$ & $?(\mathrm{~m})$ & $\boldsymbol{x}(\mathrm{m})$ & $\checkmark$ & $\checkmark$ & $n / a$ & $\checkmark$ \\
\hline Murray, 1996.31 Cross sectional & $n / a$ & $\boldsymbol{x}(\mathrm{m})$ & $?(\mathrm{~m})$ & $\checkmark$ & $\checkmark$ & $n / a$ & $n / a$ & $\boldsymbol{x}(\mathrm{m})$ \\
\hline Nordstrom et al, $1998 .{ }^{32}$ Cross sectional & $n / a$ & $?(\mathrm{M})$ & $?(\mathrm{~m}))$ & $\boldsymbol{X}(\mathrm{m})$ & $\checkmark$ & $n / a$ & $\mathrm{n} / \mathrm{a}$ & $\boldsymbol{x}(\mathrm{m})$ \\
\hline Nuttall, $1984.3^{33}$ Prospective cohort. & $n / a$ & $\checkmark$ & $?(\mathrm{~m})$ & $\boldsymbol{X}(\mathrm{m})$ & $?(\mathrm{~m})$ & $x(M)$ & $n / a$ & $\boldsymbol{x}(\mathrm{m})$ \\
\hline Nuttall, 1991. ${ }^{34}$ Prospective cohort. & $n / a$ & $?(\mathrm{M})$ & $?(\mathrm{~m})$ & $\boldsymbol{x}(\mathrm{m})$ & $\checkmark$ & $\checkmark$ & $n / a$ & $\boldsymbol{x}(\mathrm{m})$ \\
\hline Nyyssonn, 1992.35(a) Cross sectional & $n / a$ & $\boldsymbol{x}(\mathrm{m})$ & $?(\mathrm{~m})$ & $\boldsymbol{x}(\mathrm{m})$ & $?(\mathrm{~m})$ & $n / a$ & $n / a$ & $\boldsymbol{x}(\mathrm{m})$ \\
\hline Nyyssonn, V 1992. ${ }^{35(b)}$ Cross sectional & $n / a$ & $\boldsymbol{x}(\mathrm{m})$ & $?(\mathrm{~m})$ & $\boldsymbol{x}(\mathrm{m})$ & $?(\mathrm{~m})$ & $n / a$ & $n / a$ & $\boldsymbol{x}(\mathrm{m})$ \\
\hline Nyyssonn, V 1992.35(c) Cross sectional & $n / a$ & $\boldsymbol{x}(\mathrm{m})$ & $?(\mathrm{~m})$ & $\boldsymbol{x}(\mathrm{m})$ & $?(\mathrm{~m})$ & $n / a$ & $n / a$ & $\boldsymbol{x}(\mathrm{m})$ \\
\hline Palmqvist et al, $1986 .{ }^{36}$ Cross sectional & $n / a$ & $\checkmark$ & $?(\mathrm{~m})$ & $\checkmark$ & $?(\mathrm{~m})$ & $n / a$ & $n / a$ & $\boldsymbol{x}(\mathrm{m})$ \\
\hline Riordan, $1995 .{ }^{37}$ Cross sectional & $n / a$ & $\boldsymbol{x}(\mathrm{m})$ & $?(\mathrm{~m})$ & $\checkmark$ & $?(\mathrm{~m})$ & $n / a$ & $n / a$ & $\boldsymbol{x}(\mathrm{m})$ \\
\hline Rubright et al, $1996 .^{38}$ Retrospective case series & $n / a$ & $?(\mathrm{M})$ & $?(\mathrm{~m})$ & $\boldsymbol{X}(\mathrm{m})$ & $?(\mathrm{~m})$ & $n / a$ & $n / a$ & $\boldsymbol{x}(\mathrm{m})$ \\
\hline Sheiham et al, $1985 .{ }^{39}$ Cross sectional & $n / a$ & $\checkmark$ & $?(\mathrm{~m})$ & $\checkmark$ & $?(\mathrm{~m})$ & $n / a$ & $n / a$ & $\boldsymbol{x}(\mathrm{m})$ \\
\hline Wang et al, $1992 .{ }^{40}$ Controlled trial & $?(\mathrm{~m})$ & $\boldsymbol{x}(\mathrm{m})$ & $\checkmark$ & $\checkmark$ & $\boldsymbol{x}(\mathrm{m})$ & $\checkmark$ & $\checkmark$ & $\checkmark$ \\
\hline Wang and Holst, $1995 .{ }^{41}$ Cross sectional & $n / a$ & $?(\mathrm{M})$ & $?(\mathrm{~m})$ & $\checkmark$ & $\boldsymbol{x}(\mathrm{m})$ & $n / a$ & $n / a$ & $\checkmark$ \\
\hline Wang and Riordan, $1995 .{ }^{42}$ Prospective cohort & $\mathrm{n} / \mathrm{a}$ & $?(\mathrm{M})$ & $?(\mathrm{~m})$ & $\checkmark$ & $\checkmark$ & $x(M)$ & $n / a$ & $\checkmark$ \\
\hline
\end{tabular}


RESEARCH

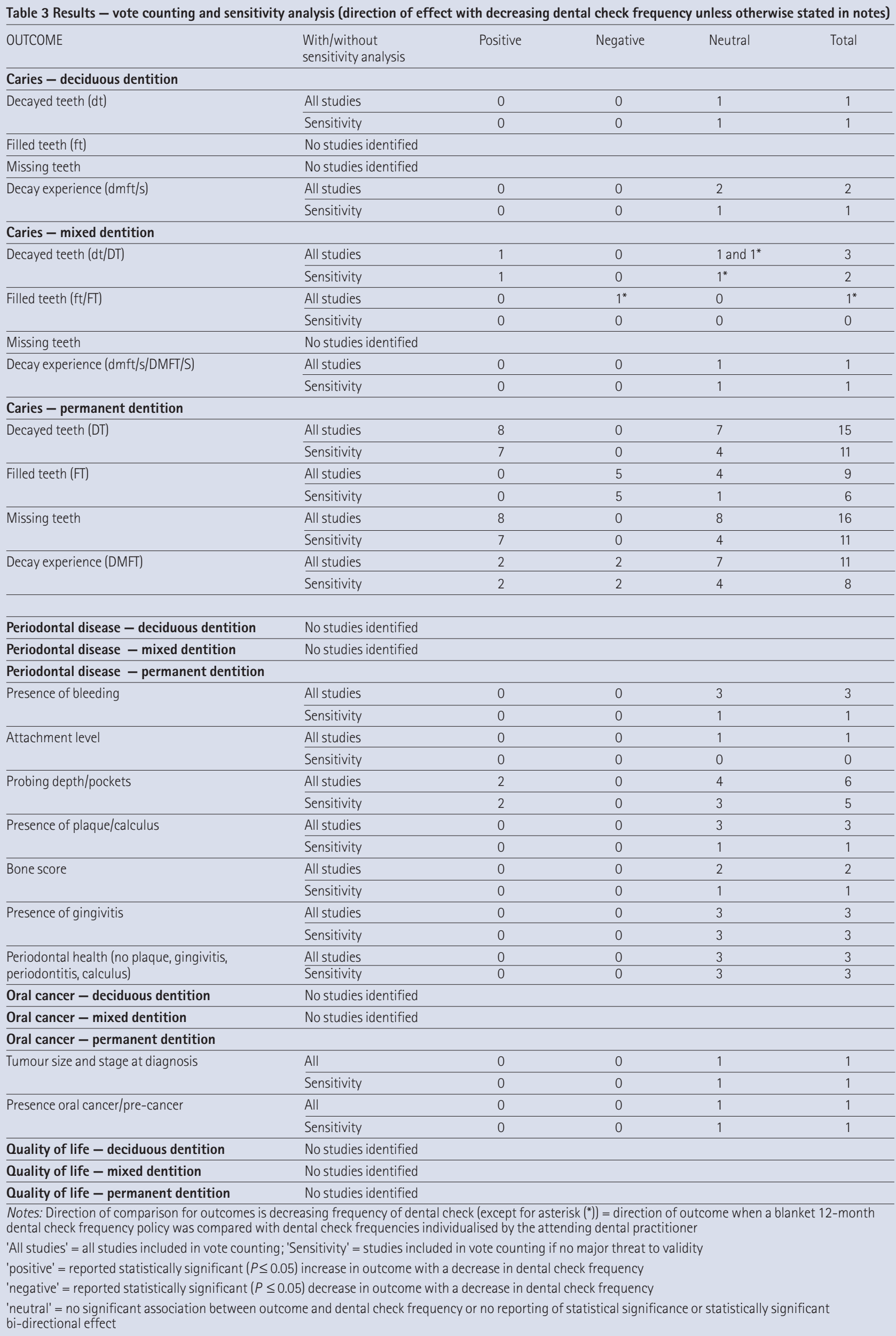


measured may be restricted to specific re-call frequencies reflecting an individual's risk of oral disease. If it had been possible to take a dichotomous approach to sensitivity analysis and select studies on the basis of their similarities (eg similar dental check frequencies or those studies more applicable to the current UK situation) then a different pattern of results may have emerged. However given the range of the differences between studies (eg country of publication, study design chosen, intervention under study, population under study, outcome measures used) and the possible interaction between these characteristics, to adopt this approach would have been potentially misleading. The heterogeneity across studies further did not allow us to formally test for the presence of publication bias.

Finally, despite our attempt to restrict studies to those representing more recent trends in treatment practice there will still be unknown variation amongst practitioners which will affect outcome measures; particularly with respect to the number of filled teeth and outcomes associated with periodontal disease. For this reason results described by the synthesis must be interpreted with caution.

\section{Implications of study for UK policy and to clinicians}

There is lack of consistency in the direction of impact on outcomes in studies that have compared different frequencies of dental check.

Moreover the majority of included studies $(22 / 28)$ have been undertaken outside of the current NHS setting. Only two studies investigating the relationship between dental check frequency and caries included six months as a dental check frequency and all other studies investigated less frequent dental check frequencies.

Modernising NHS Dentistry - Implementing the NHS Plan ${ }^{15}$ was published in September 2000. It forms the dental agenda of the modernisation programme for the NHS. It sets out the intention to redesign the NHS around patients to deliver fast, accessible care. Concerning modernisation of working patterns, the document suggests that the idea that everyone should visit the dentist every six months is one which is due for review and that by lengthening or individualising dental examination recall intervals access to NHS dentistry could be widened to a greater number of people.

This review indicates that there is no high quality evidence to either support or refute the current practice of encouraging sixmonthly dental checks in children and adults.

\section{Implications for future research}

It is clear from this review that further primary research is required in order to assess the relative effectiveness of different frequencies of dental check in terms of the separate impact on caries, periodontal disease and oral cancer. Further, clinical outcome measures and methodological approaches to assessing the impact of dental interventions need to be developed. For example the use of a composite end-point such as DMFT has the potential limitation that it may fail to reflect true changes in the underlying individual variables of which it is composed. In addition the quality of design and reporting of future research should be improved with an increased emphasis on patient-centred oral health outcomes.

However the review highlights the difficulties in evaluating public health interventions such as the provision of dental checks. The use of trials and randomisation in settings such as these can be problematic. For example it is difficult to separate the effectiveness of checks from any subsequent treatment offered and variations will exist in the way that dental checks and treatments are offered and performed. Improved use of the considerable amount of data collected routinely within the NHS dental care system provides one method for further research and evaluation in dentistry.
The authors would like to thank Adrian Boulton, Deborah Hartland and Rebecca Mason for administrative support. This review was funded by the NHS RED HTA Programme.

1. Vehkalahti M, Tarkkonen $L$, Varsio S, et al. Decrease in and polarisation of dental caries occurrence among children and youth populations, 1976-1998. Caries Res 1997; 31: 161-165.

2. Marthaler T. The prevalence of dental caries in Europe 1990-1995. Symposium report. Caries Res 1996; 30: 237-255.

3. O'Brien M. Children's dental health in the UK 1993. London: OPCS Social Survey Division, HMSO; 1993.

4. Kelly M, Steele J, Nuttall N, Bradnock G, Morris J, Nunn J, et al. Adult dental health survey: oral health in the UK 1998. London: ONS, The Stationery Office; 1998

5. Todd J E. Children's dental health in England and Wales 1973. London: HMSO; 1975.

6. Todd J E, Dodd T. Children's dental health in the United Kingdom 1983. London: HMSO 1985.

7. Todd J E, Lader D. Adult Dental Health, 1988. United Kingdom. London: OPCS; 1991.

8. Moles D R, Downer M C. Optimum bitewing examination recall intervals assessed by computer simulation. Community Dental Health 2000; 17: 14-19.

9. Anonymous. Routine six-monthly checks for dental disease? Drug Ther Bull 1985; 23: 69-72.

10. Elderton R J. Six-monthly examinations for dental caries. Br Dent J 1985; 158: 370374.

11. Kay E J. How often should we go to the dentist? Br MedJ 1999; 319: 204-205.

12. Kay EJ, Brickley M, Knill-Jones R. Restoration of approximal caries lesions-application of decision analysis. Community Dent Oral Epidemiol 1995; 23: 271-275.

13. Scottish Intercollegiate Guidelines Network. Prevention of dental caries in children at high caries risk: targeted prevention of dental caries in the permanent teeth of 6-16 year olds presenting for dental care. Edinburgh: Scottish Intercollegiate Guidelines Network; 2000.

14. NHS Executive General Dental Service Statement of Dental Remuneration Ammendment no.84. NHS Executive; 2000.

15. Department of Health, England and Wales. Modernising NHS dentistry implementing the NHS Plan 2000. URL:http://www.doh.gov.uk/pdfs/dentalstrategy.pdf

16. Wang N J, Marstrander P, Holst D, Ovrum, Dahle T. Extending recall intervals-effect on resource consumption and dental health. Community Dent Oral Epidemiol 1992; 20: 122-124.

17. Brabner D, Downer M C, Moles D R, Naylor M N. Initial caries attack and average year old Isle of Wight children. Community Dental Health 1995; 12: 190-193.

18. Khan KS, Riet G, Popay J, Nixon J, Kleijnen J. Stage II: Phase 5. Study quality assessment. In:Khan K. S, Riet G, Glanville J, Sowden A J, Kleijnen J N H S, editors. Undertaking Systematic reviews on effectiveness. CRD's guidance for those carrying out or commissioning reviews. Centre for Reviews and Dissemination, University of York; 2001.

19. Ambjornsen E. Decayed, missing, and filled teeth among elderly people in a Norwegian municipality. Acta Odontologica Scandinavica 1986; 44: 123-130.

20. Bjertness E, Eriksen H M, Hansen B F. Caries prevalence of 35-year-old Oslo citizens in 1973 and 1984. Community Dentistry Oral Epidemiol 1986; 14: 277-282.

21. Halling A, Bjorn A L. Periodontal status in relation to education and dental attendance. A 12 year longitudinal and a cross-sectional study of a random sample of dentate middle-aged women in Gothenburg. Swedish Dent J 1987; 11: 135-145.

22. Jullien J A, Downer, Zakrzewska J M, Speight P M. Evaluation of a screening test for the early detection of oral cancer and pre-cancer. Community Dent Health 1995; 12: 3-7.

23. Ketomaki T, Luoma A R. Dental caries and use of resources in relation to individual inspection interval in systematic oral health care. Helsinki, Finland: Vantaa National Research and Development Centre for Welfare and Health; 1993.

24. King N M, Ling J Y, Ng B V , Wei S H. The dental caries status and dental treatment patterns of 12-year-old children in Hong Kong [published erratum appears in J Dent Res 1987; 66: 620]. J Dent Res 1986; 65: 1371-1374.

25. Lie T, Mellingen J T. Periodontal awareness, health, and treatment need in dental school patients. II. Periodontal conditions. Acta Odontologica Scandinavica 1988; 46: 297-306.

26. Lissau I, Holst D, Friis-Hasche E. Dental health behaviors and periodontal disease indicators in Danish youths. A 10-year epidemiological follow-up. J Clin Periodontol 1990; 17: 42-47.

27. Locker D, Slade G D, Leake J L. Prevalence of and factors associated with root decay in older adults in Canada. J Dent Res 1989: 68: 768-772.

28. Lunder N. Forlengede innkallingsintervaller. Effeckter pa ressursbruk og tannhelse hos et arskull barn fra 7 til 13 ar. Norske Tannlaegeforenings Tidend e 1994; 104: 100-102.

29. Marques M D, Bjertness E, Eriksen H M. Caries prevalence of young adults in Oslo, Norway, and Porto, Portugal. A comparative analysis. Acta Odontologica Scandinavica 1994; 52: 111-115.

30. Morrant A M, Holloway P J, Taylor G 0 . A novel school dental screening programme. Community Dent Health 1995; 12: 128-132.

31. Murray J J. Attendance patterns and oral health. Br Dent J 1996; 181:339-342.

32. Nordstrom G, Bergman B, Borg K, Nilsson H, Tillberg A, Wenslov J H. A 9-year longitudinal study of reported oral problems and dental and periodontal status in 70- and 79-year-old city cohorts in northern Sweden. Acta Odontologica Scandinavica 1998: 56: 76-84.

33. Nuttall N M. General Dental Service treatment received by frequent and infrequent dental attenders in Scotland. Br Dent J 1984;156: 363-366.

34. Nuttall N M. The frequency of dental attendance of Scottish dentate adults between 1978 and 1988. BrDent J 1991; 171: 161-165. 


\section{RESEARCH}

35. Nyyssonn V. Use of oral health services and adult oral health in Finland. Proc Finnish Dent Soc 1992; 88: 33-38.

36. Palmqvist $S$ Osterberg T, Mellstrom D. Oral health and socio-economic factors in a Swedish county population aged 65 and over. Gerodontics 1986; 2: 138-142.

37. Riordan PJ. Secular changes in treatment in a school dental service. Community Dent Health 1995; 12: 221-225

38. Rubright W C, Hoffman H T, Lynch C F, Kohout FJ, Robinson R A, Graham S et al. Risk factors for advanced-stage oral cavity cancer. Archives of Otolaryngology - Head NeckSurg 1996; 122: 621-626.

39. Sheiham A, Maizels J, Cushing A, Holmes J. Dental attendance and dental status. Community Dent Oral Epidemiol 1985; 13: 304-309.

40. Wang N J, Marstrander P, Holst D, Ovrum, Dahle T. Extending recall intervals - effect on resource consumption and dental health. Community Dent Oral Epidemiol 1992; 20: $122-124$.

41. Wang $\mathrm{N}$ J, Holst $\mathrm{D}$. Individualizing recall intervals in child dental care. Community Dent Oral Epidemiol 1995; 23: 1-7.

42. Wang N J, Riordan P J. Recall intervals, dental hygienists and quality in child dental care. Community Dent Oral Epidemiol 1995; 23: 8-14.

43. Schulz K F, Chalmers I, Hayes R G, Altman D G. Empirical evidence of bias. Dimensions of methodological quality associated with estimates of treatment effects in controlled trials. J Am Med Assoc 1995; 273: 408-412.

44. Elderton $\mathrm{R} \mathrm{J}$. Longitudinal study of dental treatment in the general dental service in Scotland. BrDent J 1983; 155: 91-96.

\section{Appendix 1 Categories for assessment of quality of included studies}

Category

Yes (minor/major)

No

Unknown

Not applicable to study design

1. Selection bias and confounding

a. Was allocation to comparison

groups concealed?

b. Were the groups similar at

baseline (particularly regarding oral

health status)?

b. Was statistical adjustment made

to account for potential differences

between groups?

b. Were differences between groups

noted?

c. Is a different dental check

frequency the only 'intervention' to

explain any difference in outcome?

2. External validity

Were the eligibility criteria of the

study stated?

3. Performance bias

Were assessors blinded to

intervention allocation?

4. Attrition bias

a. Loss to follow up $<20 \%$ ?

b. Were results analysed according

to intention to treat?

5. Appropriate statistical analysis/ data presentation? 